\title{
The Combinative Effect of Organizational and Technological Eco-innovations in R\&D-intensive Companies
}

\author{
Cleonir Tumelero (corresponding author) \\ Positivo University, Business School (BS-UP) \\ 5300, Professor Pedro Viriato Parigot de Souza, 81280-330, Curitiba, PR, Brazil \\ E-mail: cleonir.tumelero@gmail.com
}

\section{Roberto Sbragia}

University of Sao Paulo, School of Economics, Business and Accounting (FEA-USP)

908, Professor Luciano Gualberto, 05508-900, Sao Paulo, SP, Brazil

E-mail: rsbragia@usp.br

Felipe Mendes Borini

University of Sao Paulo, School of Economics, Business and Accounting (FEA-USP)

908, Professor Luciano Gualberto, 05508-900, Sao Paulo, SP, Brazil

E-mail: fborini@usp.br

Received: October 6, 2020 Accepted: November 4, 2020 Published: November 23, 2020 doi:10.5296/emsd.v9i4.17786

URL: https://doi.org/10.5296/emsd.v9i4.17786

\begin{abstract}
This study aims to investigate the influence of organizational and process eco-innovations on the introduction of product eco-innovations in R\&D-intensive companies. We covered theory gaps by empirically demonstrating to what extent non-technological and technological eco-innovations are related. We used the Survey method to investigate a sample of Brazilian manufacturers from the electrical and electronics sectors, and we processed the data through Structural Equation Modeling (SEM). The findings of this study evidenced that non-technological eco-innovations are able to influence technological eco-innovations, both
\end{abstract}


process and product, suggesting that the organizational eco-innovation strategy leads to sustainable technological path dependence in R\&D-intensive companies. Additionally, findings demonstrated that the association between organizational and product eco-innovation is stronger whether mediated by process eco-innovation, so the result confirms an evolutionary perspective regarding the differentiated types of eco-innovation. We conclude that by investing in eco-innovative $\mathrm{R} \& \mathrm{D}$ projects, new environmental systems, teams' formation, information flow, and trends monitoring, the company creates a path dependence for technological eco-innovation of process and products.

Keywords: Eco-innovation, Environmental Innovation, Technological Eco-innovation, Triple Bottom Line, Technological Change, R \& D.

\section{Introduction}

Climate changes and extreme events are strong evidences of the Earth's reaction towards environmental balance (Lovelock, 1972; IPCC, 2014). Natural resources management and a better relationship with the natural environment is a priority agenda for industrial competitiveness in the 21st century. Companies can achieve this new holistic mindset by adopting eco-innovations (Shrivastava, 1995; Klassen \& Whybar, 1999; Horbach, Rammer \& Rennings, 2012; Pujari, 2006; Cheng, Yang \& Sheu, 2014; Lee \& Min, 2015). Eco-innovations are the production, assimilation or exploration of a product, production process, service or management method - which is new to the organization and results, throughout its life cycle, in the reduction of environmental risk, pollution and other negative impacts on resource use, including energy - when compared to relevant alternatives (Kemp \& Pearson, 2007).

Eco-innovations have different terminologies, such as sustainable innovation, environmental innovation and green innovation (Tariq, Badir, Tariq \& Bhutta, 2017). The eco-innovation power rests on a true reduction of natural resources' extraction and prevention of nature's damage, so the results of eco-innovations are not just economic (Klassen \& Whybar, 1999; Frondel, Horbach \& Rennings, 2004; Kemp \& Pearson, 2007; Arundel \& Kemp, 2009; Wong, 2013). The effort to introduce eco-innovations can be rewarded by the improvement of the companies' economy (Cheng \& Shiu, 2012; Cheng et al., 2014; Brasil et al., 2016; Hojnik, Ruzzier \& Manolova, 2018), social (Wagner, 2010; Shrivastava, 1995; Arena et al., 2009; Horbach et al., 2012) and socioeconomic results (Tumelero, Sbragia \& Evans, 2019).

By revising the eco-innovations theories, we identified the opportunity to cover the gap between the relation of non-technological and technological eco-innovations, complementing Song, Fisher and Kwoh (2019) theoretical study. Relations a priori of the eco-innovations, as cooperation in $\mathrm{R} \& \mathrm{D}$, and posteriori, as socioeconomic results, were already investigated by Tumelero et al. (2019). García-Granero, Piedra-Muñoz \& Galdeano-Gómez (2020) also studied relations a priori of eco-innovations, of environmental corporate culture and commercial orientation, and did not test the association between product and process eco-innovation.

So, we investigated the simultaneous relations among different types of eco-innovations, 
once previous studies have considered eco-innovation as a unit (Pujari, 2006; De Marchi, 2012), even though eco-innovations are classified as technological (product and process), and organizational, marketing, social and system (Kemp \& Pearson, 2007; EIO, 2013). According to Sanni (2018), is more appropriate to test each of these categories separately, mainly considering that non-technological eco-innovations, as green strategy, precedes technological eco-innovations of process and product (Klassen \& Whybar, 1999; Cheng \& Shiu, 2012; Hourneaux, Hrdlicka, Gomes \& Kruglianskas, 2014).

Complementing previous studies in traditional sectors, we have isolated knowledge-intensive companies in order to investigate whether active companies in the use of technological and scientific knowledge are succeeding in the eco-innovation introduction, then we investigated R\&D-intensive companies, which stand out among those that most invest in R\&D activities in Brazil (IBGE, 2016). So, this study aims to answer the following question: to what extent organizational and process eco-innovations do influence the introduction of product eco-innovation?

The findings of this study evidence that non-technological eco-innovations are able to influence technological eco-innovations, suggesting that the organizational eco-innovation strategy leads to sustainable technological path dependence. The results reinforce the importance of organizational eco-innovation (Hourneaux et al., 2014) and extend the association of non-technological to technological innovation (Le Bas, Mothe \& Nguyen-Thi, 2015) to the eco-innovation field.

We pioneering tested the capacity of Brazilian companies of electrical and electronic goods to introduce eco-innovations. Prior studies that addressed both technological (product and process) and organizational eco-innovations have mainly studied the following sectors and regions: information technologies, computers, telecommunications and integrated circuits design in Asia (Cheng \& Shiu, 2012; Cheng et al., 2014), and textile industry in Brazil (Brasil et al., 2016). Moreover, these Brazilian industries are facing the local regulations of the National Solid Waste Policy (PNRS). Although still poorly implemented, the PNRS is a first shake to compel the sectors to deepen the reduction of the carbon footprint and raise solutions for reverse logistics.

In the next section, we review the literature and propose the hypotheses of the study. Section 3 presents the method for data collecting and processing. We present the results in Section 4 and discuss the implications in Section 5. Section 6 presents the conclusions, limitations and suggestions for future studies.

\section{Literature Review}

Product eco-innovations are the introduction of goods or services that reduce the impact on the environment. Process eco-innovations are the introduction of technologies that decrease the use of materials, production inputs and risks during the production process, resulting in cost savings (Shrivastava, 1995; Frondel et al., 2004; Kemp \& Pearson, 2007; EIO, 2013). In turn, organizational eco-innovations are the introduction of methods and environmental management systems into production processes and products, which may comprise pollution 
prevention systems, management and auditing of environmental systems (e.g. EMAS and ISO 14.001), and value chain management (Kemp \& Pearson, 2007).

We can see non-technological and technological eco-innovations as differentiated innovation types. However, with the lens of Evolutionary Theory of Innovation, we can see a path dependence between these eco-innovations. The Evolutionary Theory of Innovation or Neo-Schumpeterian Perspective (Nelson \& Winter, 1982) is able to cover studies in the eco-innovation field. Evolutionary concepts, such as technology push and market pull, strategic R\&D for radical or incremental technological innovation, and network cooperation (Freeman, 1974) could be associated with an eco-innovations strategy. As well as, we can consider the innovation types (organizational, process and product) according to technological complexity.

The complementarity between process and product innovation in the development of radical and incremental innovation was highlighted by Utterback and Abernathy (1975). It is expected the dependence of product innovation concerning process innovation. The support of process innovation is a crucial factor for competitiveness (Un \& Asakawa, 2015). On the other hand, organizational innovation is the first basis to accommodate the changes caused by process and product innovation. Second, it is essential to create a workspace by means of structure, practices and new models for the creation and development of process and product innovations (Mol \& Birkinshaw, 2009). Then, we believe that an evolutionary perspective could also explain the development of eco-innovations.

\section{Hypotheses}

We structured the proposition of the hypotheses in order to explore the concepts and the relationship between organizational eco-innovation (independent variable) and the introduction of technological eco-innovations (dependent variables), as well as the relationship between technological eco-innovations of product and process.

\subsection{Relations between Organizational and Technological Eco-innovations}

Organizational innovations release a knowledge flow inside the organization that enables creativity, which, in turn, facilitates the development of technological innovations (Bharadwaj \& Menon, 2000). Organizational coordination is critical for the successful development of new products since product innovation passes through functional areas and requires a cross-functional team approach. Cross-functional activities should involve different areas, such as marketing, engineering, $\mathrm{R} \& \mathrm{D}$, production, purchasing and finance. Common results for the organizational coordination of product innovation are higher success rates and better profits, and, most important, a cycle time reduction (Cooper, 1994).

The benefits of organizational eco-innovations are especially relevant for the introduction of technological eco-innovations. Organizational eco-innovations help reduce the information deficits regarding the detection of potential cost savings, mainly in materials and energy (Porter \& Van der Linde, 1995; Horbach, 2008). In addition, they contribute to higher success in the development of eco-innovative or low-carbon products (Neto, Jabbour \& Jabbour, 2014), once product impact analysis will inevitably involve several functional areas in life 
cycle assessment (LCA) (Pujari, Wright \& Peattie, 2003). Cheng et al. (2014), Neto et al. (2014) and Brasil et al. (2016) suggest that organizational eco-innovations play a fundamental role in enhancing product eco-innovations, by favoring environmental protection and the adoption of clean and eco-efficient technologies. However, previous empirical studies, as García-Granero et al. (2020) did not test the association between organizational and product eco-innovation. In this sense, we present the first hypothesis.

$H^{l}$ : Organizational eco-innovation does influence the introduction of product eco-innovation in $R \& D$-intensive companies.

However, Cheng et al. (2014) and Brasil et al. (2016) also noted that organizational eco-innovations play a critical role in enhancing process eco-innovations. These have evolved in complexity, from reactive to proactive practices of cleaner production (Rennings, 2000; Frondel et al., 2004; Kemp \& Pearson, 2007; Horbach et al., 2012; Arundel \& Kemp, 2009; EIO, 2013) and related environmental regulation/legislation (De Marchi, 2012). The complexity regarding the introduction of process eco-innovations can be managed by introducing organizational eco-innovations, more specifically by changing the environmental management system (Porter \& Van der Linde, 1995; Horbach, 2008; Pujari et al., 2003). So, we can present the second hypothesis.

$H^{2}$ : Organizational eco-innovation does influence the introduction of process eco-innovation in $R \& D$-intensive companies.

In addition to the relationship between organizational and technological eco-innovations, we were also interested in investigating the relation between technological eco-innovations itself, of product and process. Traditional studies on innovation, not ecological, (Maine, Lubik \& Garnsey, 2012) support the relationship between technological innovations of process and product. Process innovation usually improves existing production processes with advanced techniques, which, in turn, enhances the capability of adding new product features (Maine et al., 2012). In a deeper view, innovation generates innovation (Baumol, 2002) and therefore should create a path dependency. On the other hand, empirical analyses that address the effect of different types of technological eco-innovations are scarce. Few studies (Cheng et al., 2014; Brasil et al., 2016) have tried to explore whether process eco-innovations do explain product eco-innovations. García-Granero et al., (2020), for example, studied relations a priori of eco-innovations, of environmental corporate culture and commercial orientation, and did not test the association between product and process eco-innovation. Thus, looking through the lens of evolutionary theory (Nelson \& Winter, 1982), we see the opportunity to test the relationship between technological eco-innovations of process and product, based on the evidence shown by Cheng et al. (2014) and Brasil et al. (2016) that process eco-innovations could facilitate the development of new product eco-innovations. Hence, we proposed the third hypothesis:

$H^{3}$ : Process eco-innovation does influence the introduction of product eco-innovation in $R \& D$-intensive companies.

We are proposing an evolutionary perspective of eco-innovation. Therefore, it is important to 
emphasize two points. As presented in $\mathrm{H} 1$, we admit the positive association between organizational and product eco-innovations, however, we suppose this association is stronger whether mediated by process eco-innovation.

Considering the theoretical background and the proposed hypotheses, we present the conceptual model of the study (CMS) in Figure 1, followed by the study methodology.

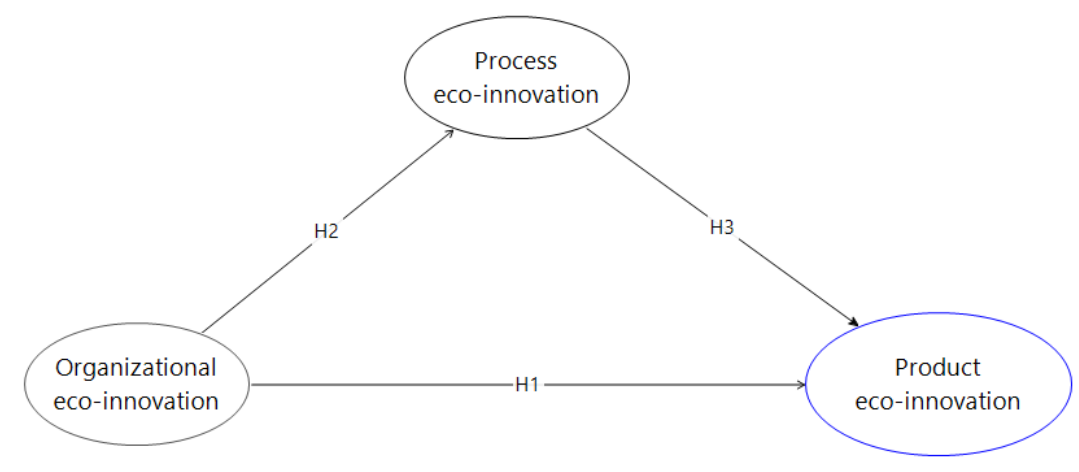

Figure 1. The Conceptual Model of the Study (CMS)

\section{Method}

In this study, we are interested in investigating the relations among eco-innovations. Considering "Sharing data procedures", we have accessed the data used by Tumelero et al. (2019) to test our model, according to the methodology description below.

The Survey method was defined (Sampieri, Collado \& Lucio, 2006). Companies from the Brazilian electronics and electrical sectors were investigated. These sectors were chosen because they stand out among the four industries which most invest in technological innovation in Brazil, which allows consider them as R\&D-intensive companies (IBGE, 2016). The universe was considered infinite, due to the lack of data regarding R\&D-intensive companies in these sectors. To calculate the necessary sample, a Multiple Linear Regression test was used from the software $G^{*}$ Power3, considering a significance level $p<0.001$.

For data collecting a questionnaire developed and validated by Cheng and Shiu (2012) was used. The questionnaire was back-translated and pre-tests were applied. The constructs were classified in independent variable (organizational eco-innovation), mediating variables (process eco-innovations) and dependent variable (product eco-innovation) (Cheng \& Shiu, 2012). After proper validity and reliability procedures, the questionnaire was considered ready for application.

A list of three thousand possible respondents was taken as a starting point. After the removal of non-adequate respondents, especially those with low technological content, 628 companies remained, which were contacted first by telephone in order to identify key respondents and after by e-mail, with a cover letter introducing the study and ensuring confidentiality.

Two new invitations were sent later for one month. On top of that, was made a new call to 
managers who did not answer the questionnaire. The application was made from March to June of 2017. A final sample of 221 valid answers was achieved. The data were processed through SmartPLS ${ }^{\circledR}$ 3, using Structural Equation Modeling (SEM) for the analyses (Henseler, Ringle \& Sinkovics, 2009; Hair, Hult, Ringle \& Sarstedt, 2014).

\section{Results}

As for the results, we firstly show the demographic profile of the sample. Second, we present the Structural Equations Modeling (SEM) statistics. Third, we check the research hypotheses.

Table 1. Demographic profile of the sample of R\&D-intensive companies

\begin{tabular}{|l|l|l|l|}
\hline Characteristics & Description & $\begin{array}{l}\text { Frequency } \\
(\mathbf{N}=\mathbf{2 2 1})\end{array}$ & $\begin{array}{l}\text { Percentage } \\
(\boldsymbol{\%})\end{array}$ \\
\hline \multirow{5}{*}{ Size } & Small (10-49 employees) & 76 & 34.4 \\
\cline { 2 - 4 } & Medium (50-249 employees) & 88 & 39.8 \\
\cline { 2 - 4 } & Large (250 or more employees) & 57 & 25.8 \\
\hline \multirow{4}{*}{\begin{tabular}{l} 
Activity \\
\cline { 2 - 4 }
\end{tabular}} & Batteries, light bulbs and other appliances & 8 & 3.6 \\
\cline { 2 - 4 } & Computing and peripherals & 16 & 7.2 \\
\cline { 2 - 4 } & Electromedical devices & 15 & 6.8 \\
\cline { 2 - 4 } & Electronic components & 37 & 16.7 \\
\cline { 2 - 4 } & Equipment for measuring, testing and control & 24 & 10.9 \\
\cline { 2 - 4 } & Generators, transformers, equipment and electrical materials & 50 & 22.6 \\
\cline { 2 - 4 } & Household appliances & 15 & 6.8 \\
\cline { 2 - 4 } & Industrial automation & 13 & 5.9 \\
\cline { 2 - 4 } & Other electrical and electronic products & 20 & 9.0 \\
\cline { 2 - 4 } & Telecommunications equipment & 23 & 10.4 \\
\hline
\end{tabular}

\subsection{Evaluation of the Measurement Model}

We present the results of the structural equation model in two stages: evaluations of the measurement model and the structural model (Henseler et al., 2009; Hair et al., 2014).

We ran three statistical tests to evaluate the reflexive latent variables of the model: (i) factorial weight; (ii) reliability of internal consistency and convergent validity; and (iii) discriminant validity (Henseler et al., 2009, Hair et al., 2014).

(i) Factorial weight

In the first processed model, three variables from the construct product eco-innovation showed loads lower than 0.7: packing (0.646), construction (0.652) and efficiency (0.663). From the step-wise method, we decided to remove these indicators, according to the criteria suggested by Henseler et al. (2009) and Hair et al. (2014).

(ii) Reliability of internal consistency and convergent validity

In Table 2 we see that Cronbach's alpha and Composite Reliability values are higher than 0.7 , and AVE values are higher than 0.5. These results validate the model's latent variables, following the criteria suggested by Fornell and Larcker (1981) and Hair et al. (2014). 


\section{Al Macrothink \\ Environmental Management and Sustainable Development \\ ISSN 2164-7682 \\ 2020, Vol. 9, No. 4}

Table 2. Reliability of internal consistency and convergent validity

\begin{tabular}{|l|c|c|l|}
\hline Construct & Cronbach's alpha & Composite Reliability & AVE \\
\hline org_eco-innovation & 0.934 & 0.948 & 0.754 \\
\hline proc_eco-innovation & 0.898 & 0.925 & 0.711 \\
\hline prod_eco-innovation & 0.893 & 0.921 & 0.700 \\
\hline
\end{tabular}

(iii) Discriminant validity

By evaluating the indicators' cross-loads, we observe that the highest shared load of each indicator relates to their respective constructs. Such results provide a first indication of the constructs' discriminant validity. For the Fornell-Larcker Criterion, we observe, in Table 3, that the constructs have values of AVE square root higher than their correlations with any other construct, which indicates the discriminant validity of the constructs (Fornell \& Larcker, 1981; Hair et al., 2014).

Table 3. Discriminant validity of reflexive variables

\begin{tabular}{|l|l|l|l|l|l|}
\hline Construct & AVE & \multirow{2}{*}{ AVE Square root } & \multicolumn{2}{|l|}{ Correlation coefficient } & \\
\cline { 4 - 6 } & & & eco_organizational & eco_process & eco_product \\
\hline org_eco-innovation & 0.754 & $\mathbf{0 . 8 6 8}$ & 1 & - & - \\
\hline proc_eco-innovation & 0.711 & $\mathbf{0 . 8 4 3}$ & 0.674 & 1 & - \\
\hline prod_eco-innovation & 0.700 & $\mathbf{0 . 8 3 7}$ & 0.740 & 0.694 & 1 \\
\hline
\end{tabular}

\subsection{Evaluation of the Structural Model}

To evaluate the structural model, we used: (i) multicollinearity; (ii) coefficients of the structural model path and (iii) coefficients of determination.

(i) Multicollinearity analysis

We carried out the multicollinearity analysis by using the Variance Inflation Factor (VIF), which showed that all ratios present VIF values below 5.00; this does not indicate the existence of multicollinearity and validates the constructs for the model composition (Hair et al., 2014).

(ii) Coefficients of the Structural Model Path

From the analysis of path coefficients $(\beta)$, we observed that the model presented all path coefficients above 0.20 , showing significant relations. The final significance was obtained through the Student t-test and the Bootstrapping technique, in order to check the standard error. We reprocessed data 1000 times to estimate the path significance from the original coefficients plus the standard error of each path. A minimum confidence level of $99 \%$ $(\alpha<0.01)$ was defined to obtain $t$ values higher than 2.57. These results (Figure 2) demonstrate that, ultimately, the coefficients present valid relationships for the model composition (Hair et al., 2014). 


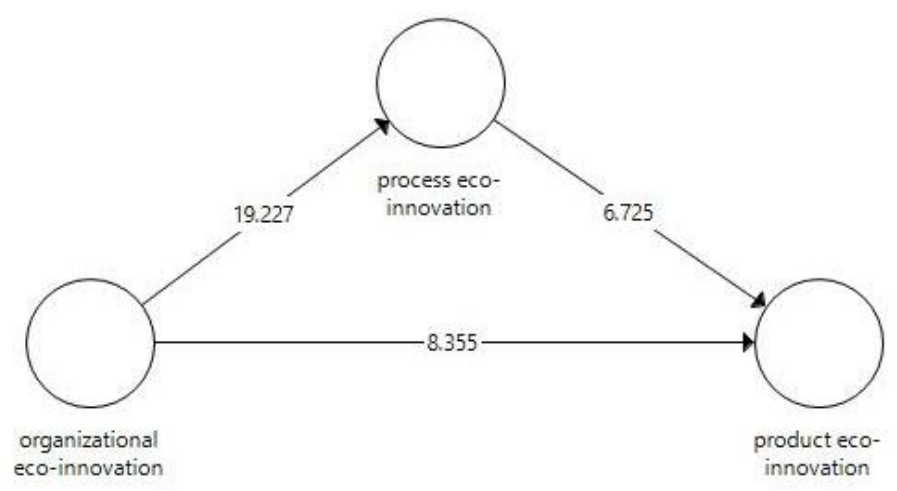

Figure 2. Path coefficients

(iii) Coefficients of determination

Figure 3 shows the coefficients of determination $\left(\mathrm{R}^{2}\right)$. The main coefficient, of the dependent variable product eco-innovation, presents a substantial result of $\mathrm{R}^{2}=0.618$, which indicates that organizational and process eco-innovations explain the product eco-innovation introduction in R\&D-intensive companies in $61.8 \%$. We also observe that organizational eco-innovations explain process eco-innovation in $45.4 \%$. Such results support the conclusion that the determining coefficients are suitable for the final validation.

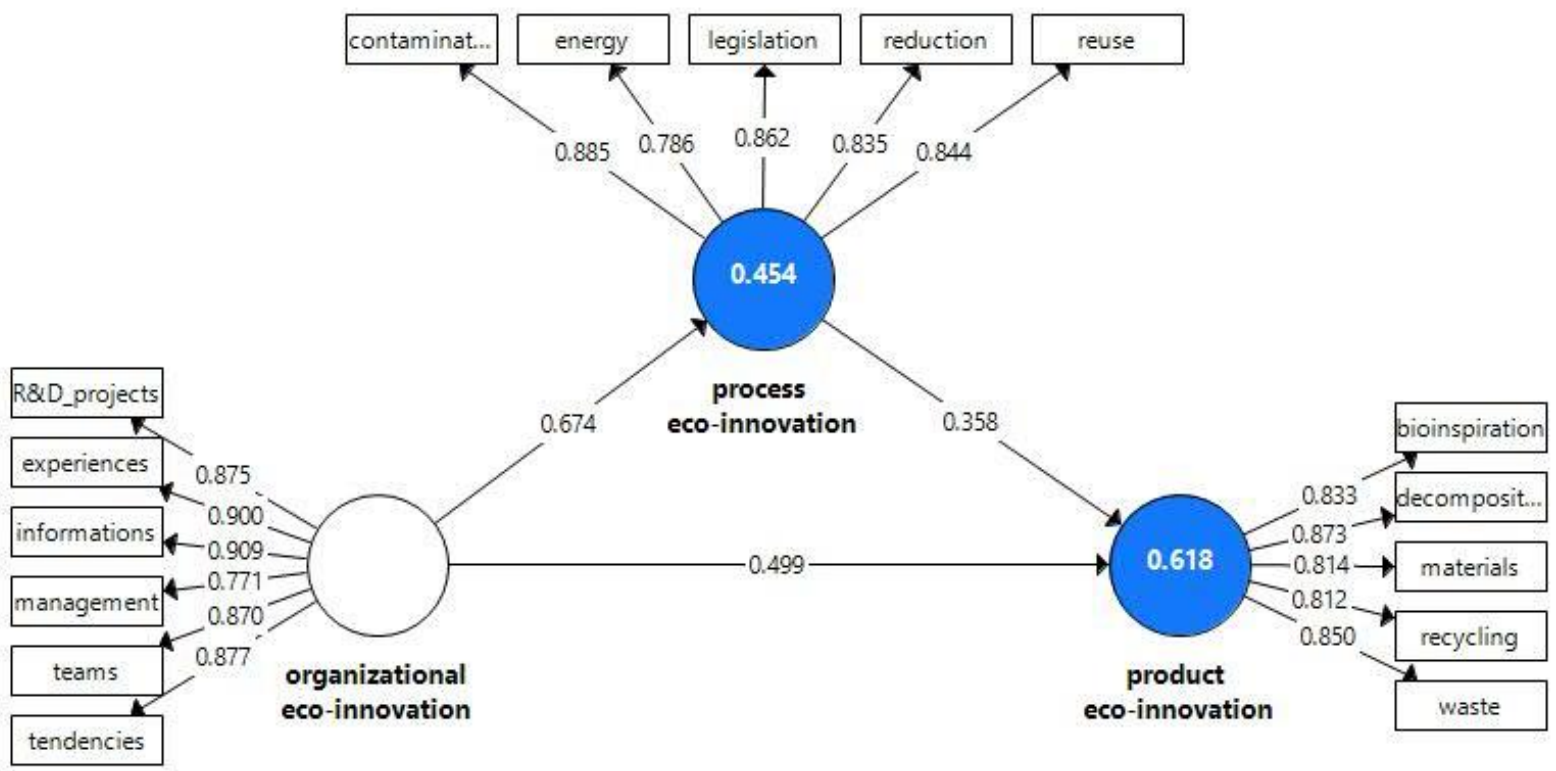

Figure 3. The model's coefficients of determination

\subsection{Research Hypotheses Analysis}

We carried out the nomological validation of the research hypotheses from the $p$-value and path coefficient criteria. For the p-value, we defined a minimum confidence level of $99 \%$ 
$(\alpha<0.01)$, and values higher than 0.20 for the path coefficients. In addition, we present in Table 4 the $t$ Student test values, although both led to the same conclusion (Hair et al., 2014). In face of the accomplished tests, hypothesis $\mathrm{H}^{1}, \mathrm{H}^{2}$ and $\mathrm{H}^{3}$ were confirmed at the confidence level of $99 \%$.

Table 4. The research hypotheses tests

\begin{tabular}{|l|l|l|l|}
\hline Hypothesis & $\begin{array}{l}\text { p-value } \\
(\boldsymbol{\alpha}<\mathbf{0 . 0 1})\end{array}$ & $\begin{array}{l}\text { Path } \\
\text { Coefficient }\end{array}$ & Situation \\
\hline $\begin{array}{l}\text { H1: Organizational eco-innovation does influence the introduction } \\
\text { of product eco-innovation in R\&D-intensive companies. }\end{array}$ & 0.000 & $\begin{array}{l}0.4995>0.20 \\
(8.355>2.57)\end{array}$ & Confirmed \\
\hline $\begin{array}{l}\text { H2: Organizational eco-innovation does influence the introduction } \\
\text { of process eco-innovation in R\&D-intensive companies. }\end{array}$ & 0.000 & $\begin{array}{l}0.674>0.20 \\
(19.227>2.57)\end{array}$ & Confirmed \\
\hline $\begin{array}{l}\text { H3: Process eco-innovation does influence the introduction } \\
\text { of product eco-innovation in R\&D-intensive companies. }\end{array}$ & 0.000 & $\begin{array}{l}0.358>0.20 \\
(6.725>2.57)\end{array}$ & Confirmed \\
\hline
\end{tabular}

Once $\mathrm{H} 1, \mathrm{H} 2$, and $\mathrm{H} 3$ are confirmed, we need to check whether the evolutionary perspective of the eco-innovation makes sense. As before anticipated, we admit the positive association between organizational and product eco-innovations, however, we suppose this association is stronger whether mediated by process eco-innovation. So, the Sobel, Aroian and Goodman tests were applied. The result indicates approximate values of $t=6.34$, which confirms the existence of the mediation of process eco-innovation. Complementary, the VAF test presented a value of 0.326 , which allow considering partial mediation. The result confirms the mediation of process eco-innovation and an evolutionary perspective regarding the differentiated types of the eco-innovation.

\section{Discussion}

The results demonstrated that $\mathrm{R} \& \mathrm{D}$-intensive companies were able to jointly introduce technological (product and process) and organizational eco-innovations. Results indicate that organizational eco-innovations stand out as a construct, since it presents major convergent and discriminant validity, compared to process and product eco-innovations. We confirmed previous studies that also addressed non-technological and technological eco-innovations in information technologies, computers, telecommunications and integrated circuits design, in Asia (Cheng \& Shiu, 2012; Cheng et al., 2014), and in textile industry, in Brazil (Brasil et al., 2016).

The confirmation of hypotheses $\mathrm{H}^{1}$ and $\mathrm{H}^{2}$ demonstrated that organizational eco-innovations positively influenced the introduction of technological eco-innovations in R\&D-intensive companies. Our results demonstrated that organizational eco-innovations have a higher influence on the introduction of process than of product eco-innovations. These results support previous studies by Cheng et al. (2014) and Brasil et al. (2016), who investigated these relations in companies of other economic sectors. As well anticipated by Cooper (1994), organizational coordination is critical for the successful development of new products, since product innovation goes through functional areas and requires a cross-functional team approach. We add novelty to previous findings by showing that Cooper's statement is also valid for environmental innovations, not only related to products but also processes. We call 
attention to the flow of knowledge spread in the company from organizational eco-innovations, by considering that this knowledge can reduce information gaps, increase creativity and disruption of products, and decrease the technological complexity of processes' cleaner production.

The confirmation of hypothesis $\mathrm{H}^{3}$ showed that the introduction of process eco-innovations positively affects the introduction of product eco-innovations in R\&D-intensive companies. We contribute to previous studies in the traditional innovation field, not ecological (Maine et al., 2012), that supported the positive relationship between technological innovations of process and product, by demonstrating that advanced process techniques inevitably will improve the ability to add new product features. We also corroborate studies of Cheng et al. (2014) and Brasil et al. (2016), which demonstrated that the process indeed explains product eco-innovations.

Finally, we emphasize the importance of organizational eco-innovations, not only as a background for technological eco-innovations but also because the construct has both positive influence on process and product from an evolutionary perspective of these differentiated types of eco-innovation. At the same time, former studies stated that organizational innovation could influence technological innovation (Le Bas et al., 2015). Then, again, we arrived at the same results for eco-innovation. In the end, these results suggest that theories from the traditional innovation field also support studies in the eco-innovation field.

\section{Conclusions}

The research question of this study was: to what extent organizational and process eco-innovations do influence the introduction of product eco-innovation? We concluded that the combined ability to introduce organizational and process eco-innovations positively affects the introduction of product eco-innovations in R\&D-intensive companies in $61.8 \%$. In other words, companies that have the combined capacity to introduce methods and environmental management systems (organizational eco-innovations) and use cleaner process (process eco-innovations) positively influence the reduction of the environmental impact (product eco-innovations).

We demonstrated the positive influence of process on product eco-innovations, so we can conclude that eco-innovation leads to eco-innovation, similarly to Baumol (2002), who observed that innovation leads to innovation. By reducing the use of materials, production inputs and risks during production, process eco-innovations result not only in cost savings but also in the introduction of goods or services that decrease the impact on the environment. In other words, it is possible to assume an environmental path dependency, since competencies built in a cleaner process will positively influence the development of eco-products. This means that to invest in eco-innovative R\&D projects, the company need creates a background to the technological eco-innovation introduction. By creating an environmental path dependency in a cleaner process, the company is able to introduce clean technologies' products into the market. 


\section{Macrothink}

We finish reporting a limitation of the study regarding the generalization of the results. As we used a non-random sample, the results are restricted to manufacturing companies of the Brazilian electrical and electronics sectors. As for future studies, we see the opportunity to develop an eco-innovation management model, to investigate creative techniques for eco-innovations development, how to overcome technical complexity and how to improve eco-innovations theories from multidisciplinary approaches.

\section{Acknowledgment}

We thank to the Coordenação de Aperfeiçoamento de Pessoal de Nível Superior (CAPES) for the financial suport, and we thank to the Editors and Reviewers for their important contributions.

\section{References}

Arena, M., Ciceri, N., Terzi, S., Bengo, I., Azzone, G., \& Garetti, M. (2009). A state-of-the-art of industrial sustainability: definitions, tools and metrics. International Journal of Product Lifecycle Management, 4(1-3), 207-251.

https://doi.org/10.1504/IJPLM.2009.031674

Arundel, A., \& Kemp, R. (2009). Measuring eco-innovation. [Working Paper Series \#2009-017]. United Nations University (UNU-MERIT). [Online] Available:

www.merit.unu.edu/publications/wppdf/2009/wp2009-017.pdf

Baumol, W. J. (2002). The free-market innovation machine: Analyzing the growth miracle of capitalism. Princeton, NJ: Princeton University Press.

https://doi.org/10.1515/9781400851638

Bharadwaj, S., \& Menon, A. (2000). Making innovation happen in organizations: individual creativity mechanisms, organizational creativity mechanisms or both?. Journal of Product Innovation Management, 17(6), 424-434. https://doi.org/10.1111/1540-5885.1760424

Brasil, M. V. O., Abreu, M. C. S., Filho, J. C. L. S., \& Leocádio, A. L. (2016). Relationship between eco-innovations and the impact on business performance: an empirical survey research on the Brazilian textile industry. Revista de Administração, 51(3), 276-287.

https://doi.org/10.1016/j.rausp.2016.06.003

Cheng, C. C., \& Shiu, E. C. (2012). Validation of a proposed instrument for measuring eco-innovation: An implementation perspective. Technovation, 32(6), 329-344.

https://doi.org/10.1016/j.technovation.2012.02.001

Cheng, C. C. J., Yang, C-L., \& Sheu, C. (2014). The link between eco-innovation and business performance: A Taiwanese industry context. Journal of Cleaner Production, 64, 81-90. https://doi.org/10.1016/j.jclepro.2013.09.050

Cooper, R. G. (1994). New Products: The factors that drive success. International Marketing Review, 11(1), 60-76. https://doi.org/10.1108/02651339410057527

De Marchi, V. (2012). Environmental innovation and R\&D cooperation: Empirical evidence 
from Spanish manufacturing firms. Research Policy, 41(3), 614-623.

https://doi.org/10.1016/j.respol.2011.10.002

Eco-Innovation Observatory. (2013). Europe in transition: Paving the way to a green economy through eco-innovation. [Online] Available:

http://www.eco-innovation.eu/index.php/reports/annual-reports?download=35:europe-in-tran sition

Elkington, J. (1999). Cannibals with forks: The Triple Bottom Line of 21 st century business. Capstone: Oxford. https://doi.org/10.1002/tqem.3310080106

Fornell, C., \& Larcker, D. (1981). Evaluating structural equation models with unobservable variables and measurement error. Journal of Marketing, 18(1), 39-50.

https://doi.org/10.2307/3151312

Freeman, C. (1974). The Economics of Industrial Innovation. London: Penguin Books

Frondel, M., Horbach, J., \& Rennings, K. (2004). End-of-pipe or cleaner production? An empirical comparison of environmental innovation decisions across OECD countries. Center for European Economic Research [Discussion Paper No. 04-82]. [Online] Available: http://ftp.zew.de/pub/zew-docs/dp/dp0482.pdf

García-Granero, E. M., Piedra-Muñoz, L., \& Galdeano-Gómez, E. (2020). Measuring eco-innovation dimensions: The role of environmental corporate culture and commercial orientation. Research Policy, 49(8). https://doi.org/10.1016/j.respol.2020.104028

Hair, F. J., Hult, G. T. M., Ringle, C. M., \& Sarstedt, M. (2014). A primer on partial least squares structural equation modeling (PLS-SEM). Thousand Oaks, CA: Sage Publications.

Henseler, J., Ringle, C. M., \& Sinkovics, R. R. (2009). The use of partial least squares path modeling in international marketing. Advances in International Marketing, 20, 277-319. https://doi.org/10.1108/S1474-7979(2009)0000020014

Hojnik, J., Ruzzier, M., \& Manolova, T. S. (2018). Internationalization and economic performance: The mediating role of eco-innovation. Journal of Cleaner Production, 171, 1312-1323. https://doi.org/10.1016/j.jclepro.2017.10.111

Horbach, J. (2008). Determinants of environmental innovation-New evidence from German panel data sources. Research Policy, 37(1), 163-173.

https://doi.org/10.1016/j.respol.2007.08.006

Horbach, J., Rammer, C., \& Rennings, K. (2012). Determinants of eco-innovations by type of environmental impact: The role of regulatory push/pull, technology push and market pull. Ecological Economics, 78, 112-122. https://doi.org/10.1016/j.ecolecon.2012.04.005

Hourneaux, F., Hrdlicka, H. A., Gomes, C. M., \& Kruglianskas, I. (2014). The use of environmental performance indicators and size effect: A study of industrial companies. Ecological Indicators, 36, 205-212. https://doi.org/10.1016/j.ecolind.2013.07.009

Instituto Brasileiro de Geografia e Estatística [IBGE] (2016). Classificação Nacional de 
Atividades Econômicas (CNAE). [Online] Available: http://www.cnae.ibge.gov.br/

Intergovernmental Panel on Climate Change [IPCC] (2014). Climate change 2014 synthesis report summary for policymakers. [Online] Available:

https://www.ipcc.ch/pdf/assessment-report/ar5/syr/AR5_SYR_FINAL_SPM.pdf

Kemp, R., \& Pearson, P. (2007). Final report MEI project about measuring eco-innovation. [Online] Available: https://www.oecd.org/env/consumption-innovation/43960830.pdf

Klassen, R. D., \& Whybar, D. C. (1999). The Impact of Environmental Technologies on Manufacturing Performance. Academy of Management Journal, 42(6), 599-615. https://doi.org/10.2307/256982

Le Bas, C., Mothe, C., \& Nguyen-Thi, T. U. (2015). The differentiated impacts of organizational innovation practices on technological innovation persistence. European Journal of Innovation Management, 18(1), 110-127.

https://doi.org/10.1108/EJIM-09-2012-0085

Lee, K-H., \& Min, B. (2015). Green R\&D for eco-innovation and its impact on carbon emissions and firm performance. Journal of Cleaner Production, 108, 534-542.

https://doi.org/10.1016/j.jclepro.2015.05.114

Lovelock, J. E. (1972). Gaia as seen through the atmosphere. Atmospheric Environment, 6, 579-580. https://doi.org/10.1016/0004-6981(72)90076-5

Maine, E., Lubik, S., \& Garnsey, E. (2012). Process-based vs. product-based innovation: Value creation by nanotech ventures. Technovation, 32(3-4), 179-192.

https://doi.org/10.1016/j.technovation.2011.10.003

Mol, M. J., \& Birkinshaw, J. (2009). The sources of management innovation: When firms introduce new management practices. Journal of Business Research, 62(12), 1269-1280. https://doi.org/10.1016/j.jbusres.2009.01.001

Nelson, R. R., \& Winter, S. G. (1982). An evolutionary theory of economic change. Cambridge: Harvard University Press.

Neto, A. S., Jabbour, C. J. C., \& Jabbour, A. B. L. S. (2014). Green training supporting eco-innovation in three Brazilian companies: practices and levels of integration. Industrial and Commercial Training, 46(7). https://doi.org/10.1108/ICT-02-2014-0010

Porter, M. E., \& Van der Linde, C. (1995). Toward a new conception of the environment-competitiveness relationship. Journal of Economic Perspectives, 9(4), 97-118. https://doi.org/10.1257/jep.9.4.97

Pujari, D. (2006). Eco-innovation and new product development: understanding the influences on market performance. Technovation, 26(1), 76-85.

https://doi.org/10.1016/j.technovation.2004.07.006

Pujari, D., Wright, G., \& Peattie, K. (2003). Green and competitive: Influences on environmental new product development performance. Journal of Business Research, 56(8), 
657-671. https://doi.org/10.1016/S0148-2963(01)00310-1

Rennings, K. (2000). Redefining innovation - eco-innovation research and the contribution from ecological economics. Ecological Economics, 32, 319-332.

https://doi.org/10.1016/S0921-8009(99)00112-3

Sampieri, R. H, Collado, C. F., \& Lucio, P. B. (2006). Metodologia de pesquisa. (3a ed.). São Paulo: McGraw-Hill.

Sanni, M. (2018). Drivers of eco-innovation in the manufacturing sector of Nigeria. Technological Forecasting and Social Change, 131, 303-314.

https://doi.org/10.1016/j.techfore.2017.11.007

Shrivastava, P. (1995). Environmental technologies and competitive advantage. Strategic Management Journal, 16, 183-200. https://doi.org/10.1002/smj.4250160923

Song, M., Fisher, R., \& Kwoh, Y. (2019). Technological challenges of green innovation and sustainable resource management with large scale data. Technological Forecasting and Social Change, 144, 361-368. https://doi.org/10.1016/j.techfore.2018.07.055

Tariq, A., Badir, Y. F., Tariq, W., \& Bhutta, U. S. (2017). Drivers and consequences of green product and process innovation: A systematic review, conceptual framework, and future outlook. Technology in Society, 51, 8-23. https://doi.org/10.1016/j.techsoc.2017.06.002

Tumelero, C., Sbragia, R., \& Evans, S. (2019). Cooperation in R \& D and eco-innovations: The role in companies' socioeconomic performance. Journal of Cleaner Production, 207, 1138-1149. https://doi.org/10.1016/j.jclepro.2018.09.146

Un, C. A., \& Asakawa, K. (2015). Types of R\&D collaborations and process innovation: The benefit of collaborating upstream in the knowledge chain. Journal of Product Innovation Management, 32(1), 138-153. https://doi.org/10.1111/jpim.12229

Utterback, J. M., \& Abernathy, W. J. (1975). A dynamic model of process and product innovation. Omega, 3(6), 639-656. https://doi.org/10.1016/0305-0483(75)90068-7

Wagner, M. (2010). Corporate social performance and innovation with high social benefits: A quantitative analysis. Journal of Business Ethics, 94(4), 581-594.

Wong, S. K. S. (2013). Environmental requirements, knowledge sharing and green innovation: empirical evidence from the electronics industry in China. Business Strategy and the Environment, 22(5), 321-338. https://doi.org/10.1002/bse.1746

\section{Copyright Disclaimer}

Copyright for this article is retained by the author(s), with first publication rights granted to the journal.

This is an open-access article distributed under the terms and conditions of the Creative Commons Attribution license (http://creativecommons.org/licenses/by/4.0/). 